\title{
PRODUCTIVE PERFORMANCE OF CARROT AND COWPEA INTERCROPPING SYSTEM UNDER DIFFERENT SPATIAL ARRANGEMENTS AND POPULATION DENSITIES ${ }^{1}$
}

\author{
GIORGIO MENDES RIBEIRO ${ }^{2 *}$, FRANCISCO BEZERRA NETO ${ }^{2}$, JAILMA SUERDA SILVA DE LIMA ${ }^{2}$, MAIELE \\ LEANDRO DA SILVA ${ }^{3}$, AURÉLIO PAES BARROS JÚNIOR ${ }^{2}$, ELIZANGELA CABRAL DOS SANTOS ${ }^{2}$
}

\begin{abstract}
Spatial arrangement and population density of component cultures, when well structured, may contribute to increased crop yields relative to monocultures. Thus, the objective of this work was to evaluate the productive performance of carrot and cowpea in an intercropping system under different spatial arrangements and population densities. This research was conducted on the "Rafael Fernandes" experimental farm of the Universidade Federal Rural do Semi-Árido (UFERSA), Mossoró, RN, Brazil. The experimental design was a randomized complete block with four replicates, where the treatments were arranged in a $3 \times 4$ factorial scheme, in which the first factor was three spatial arrangements $(2: 2,3: 3$, and 4:4) and the second factor was four different population densities of cowpea $(100 \%, 80 \%, 60 \%$, and $40 \%$ of the recommended population in the single crop [RPSC]). Rooster tree Calotropis procera (Ait.) R.Br., a spontaneous species of the 'Caatinga' biome, was used as fertilizer. The characteristics evaluated in carrot were as follows: total and commercial productivity of roots and classified root production. The following characteristics were evaluated for cowpea: number of pods per square meter, length and yield of green pods, number of grains per pod, 100grain weight, and yield of green grains. The modified monetary advantage was used to evaluate the feasibility of the intercropped systems. Spatial arrangements between the component cultures did not influence the agroeconomic performance of the carrot-cowpea intercropping system. The highest agro-economic performance of the carrot-cowpea intercropping was obtained in the population of cowpea, which was $42 \%$ of the RPSC.
\end{abstract}

Keywords: Daucus carota. Vigna unguiculata. Calotropis procera. Production assessment.

\section{DESEMPENHO PRODUTIVO DO SISTEMA CONSORCIADO DE CENOURA E FEIJÃO-CAUPI SOB DIFERENTES ARRANJOS ESPACIAIS E DENSIDADES POPULACIONAIS}

RESUMO - O arranjo espacial e a densidade populacional das culturas componentes quando bem estruturados podem contribuir para aumentar os rendimentos das culturas em relação ao monocultivos. Assim, o objetivo deste trabalho foi avaliar o desempenho produtivo da cenoura e do feijão-caupi em sistema consorciado sob diferentes arranjos espaciais e densidades populacionais. Essa pessquisa foi conduzida na fazenda experimental "Rafael Fernandes" da Universidade Federal Rural do Semi-Árido (UFERSA), Mossoró, RN, Brasil. O delineamento experimental foi de blocos completos casualizados com quatro repetições, em esquema fatorial 3 x 4 em que o primeiro fator foi três arranjos espaciais (2: 2, 3:3 e 4:4) e o segundo fator quatro densidades populacionais de feijão-caupi $(100,80,60$ e $40 \%$ da população recomendada no cultivo solteiro - PRCS). O experimento foi adubado com flor-de-seda (Calotropis procera (Ait.) R.Br.), uma espécie espontânea do bioma Caatinga. As características avaliadas na cenoura foram: produtividade total e comercial de raízes e produtividade classificada de raízes. Para o feijão-caupi foi avaliado as seguintes características: número de vagens por metro quadrado, comprimento e produtividade de vagens verdes, número de grãos por vagem, peso de 100 grãos e produtividade de grãos verdes. A vantagem monetária corrigida foi utilizada para avaliar a viabilidade dos sistemas consorciados. Não se observou influencia dos arranjos espaciais entre as culturas componentes no desempenho agroeconômico do consórcio de cenoura x feijão-caupi. A mais alta performance agroeconômica do consórcio cenoura x feijão-caupi foi obtida na densidade populacional de caupi de $42 \%$ da PRCS.

Palavras-chave: Daucus carota. Vigna unguiculata. Calotropis procera. Avaliação de produção.

\footnotetext{
${ }^{*}$ Corresponding author

${ }^{1}$ Received for publication in 06/07/2016; accepted in 06/26/2017.

Paper extracted from the doctoral dissertation of the first author.

${ }^{2}$ Department of Plant Science, Universidade Federal Rural do Semi-Árido, Mossoró, RN, Brazil; giorgio@ufersa.edu.br, bezerra@ufersa.edu.br, jailma@ufersa.edu.br, aurelio.barros@ufersa.edu.br, elizangelacabral@ufersa.edu.br.

${ }^{3}$ Department of Agronomy, Universidade Estadual de Mato Grosso do Sul, Aquidauana, MS, Brazil; maiele_engenharia@yahoo.com.br.
} 


\section{INTRODUCTION}

Intercropping systems constitute an alternative method for increasing the productivity of vegetable crops in semi-arid regions through a greater use of environmental resources. Because it is an easy-to-implement practice, it allows a higher density of plants per unit area by improving the soil cover, diversifying the production, and reducing the risk of system failure (CECÍLIO FILHO; REZENDE; CANATO, 2007). The increase of productivity in this system depends, among other factors, on its management and on the cultures involved (CECÍLIO FILHO et al., 2011). The proper management of the factors of production, such as spatial arrangement of crops, population density, and planting density, among others, can reduce competition for the use of resources.

In the intercropped system, the ideal population of crops is related to the soil's ability to provide nutrients and the ability of each crop to compete for water, light, and nutrients (ZANINE; SANTOS, 2004). However, it is necessary to consider the mutual benefits to species when composing the system and to use an adequate design for the crop arrangement with respect to the density and spacing of each component crop (ALTIERI; SILVA; NICHOLLS, 2003). Therefore, the competition depends on the population, arrangement of the plants, environmental and soil conditions, and interactions between the intercropped crops.

Planting density can be defined as the number of plants per unit area. The proposals of spacing and density of planting, for crops in general, have sought to meet the specific needs of the crop traits and improvement of productivity (BEZERRA NETO et al., 2005). However, planting density is one of the main factors that influence the development of plants. This factor promotes competition between individuals of the same species, and of different species, for growth resources such as water, light, and nutrients, and may affect production and its components (LOPES et al., 2008).

The influence of plant density on the quality of oleraceous plants has been evidenced in studies conducted in northeastern Brazil's semi-arid conditions (BEZERRA NETO et al., 2005). Studying the association of population density of carrot and lettuce in strip-intercropping, they observed that an increase in the carrot and lettuce population density increased the total and commercial productivity of carrot.

On the other hand, the spatial arrangement as a management factor can be manipulated to improve the use of environmental resources and efficiency of vegetable intercropping systems, defining the distribution pattern of the plants in relation to the soil, and determining the shape of the area available for each individual plant.

Planting in an intercropping system may involve different configurations such as the use of two plant species in alternated rows, or even in complex intercrops among several species. The arrangement of plants influences the microclimate, i.e., the availability of light, nutrients, water, and temperature, among other factors (JAUER et al., 2006). With better light interception and more efficient utilization of available water and nutrients, productivity can be improved by reducing the spacing between lines of crops and thus increasing the sowing density.

The present work aimed to evaluate the productive performance of carrot and cowpea in an intercropping system under different spatial arrangements and population densities.

\section{MATERIAL AND METHODS}

The study was carried out at the Rafael Fernandes experimental farm, belonging to the Universidade Federal Rural do Semi-Árido (UFERSA) located in the district of Alagoinha, $20 \mathrm{~km}$ from the Mossoró municipality ( $5^{\circ} 11^{\prime} \mathrm{S}$ and $37^{\circ} 20^{\prime} \mathrm{W}$ ). The climate is semi-arid, dry, and very hot, with two climatic seasons: a drought season, which usually extends from June to January, and a rainy season, from February to May (OLIVEIRA et al., 2015). During the experimental period, the average temperature was $27^{\circ} \mathrm{C}$, minimum average temperature was $22{ }^{\circ} \mathrm{C}$, maximum average temperature was $32{ }^{\circ} \mathrm{C}$, mean relative humidity was $67 \%$, average wind speed was $4 \mathrm{~ms}^{-1}$, average radiation was $23.39 \mathrm{~mJ} \mathrm{~m}^{-2}$, rainfall was $0 \mathrm{~mm}$, average atmospheric pressure was $1009 \mathrm{hPa}$, and average dew point temperature was $19^{\circ} \mathrm{C}$.

The soil of the experimental area was classified as Dystrophic Red-Yellow Latosol (EMBRAPA, 2009). Simple soil samples were collected at the experiment site with the help of a Dutch drill at a depth of $0-20 \mathrm{~cm}$ and then homogenized to obtain a composite sample, which was sent for analysis in the Soil Fertility and Plant Nutrition Laboratory at the Department of Environmental and Technological Sciences of UFERSA. The results of this analysis were as follows: $\mathrm{pH}$ (water) = 7.09; organic matter $=11.5 \mathrm{mg} \mathrm{dm}{ }^{-3} ; \mathrm{N}=0.04 \mathrm{~g} \mathrm{~kg}^{-1}$;

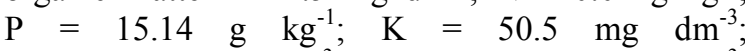
$\mathrm{Na}=4.1 \mathrm{mg} \mathrm{dm} ; \quad \mathrm{Ca}=1.84 \mathrm{cmol}_{\mathrm{c}} \mathrm{dm}^{-3} ;$ $\mathrm{Mg}=1.39 \mathrm{cmol}_{\mathrm{c}} \mathrm{dm}^{-3}$; and $\mathrm{CEC}=3.38 \mathrm{cmol}_{\mathrm{c}} \mathrm{dm}^{-3}$.

The experiment was designed in randomized complete blocks; the treatments were arranged in a $3 \times 4$ factorial scheme with four replicates. The first factor consisted of three spatial arrangements $(2: 2,3: 3$, and $4: 4)$ that corresponded to rows of carrot 'Brasília', alternated with rows of cowpea 'BRS Itaim'. The second factor was the population density of cowpea $(40 \%, 60 \%, 80 \%$, and $100 \%$ of the recommended population in the single crop

Rev. Caatinga, Mossoró, v. 31, n. 1, p. 19 - 27, jan. - mar., 2018 
[RPSC]).

The intercropping system was established in alternated strips of the component crops (carrot and cowpea) in a 1:1 ratio. The plots consisted of two, three, and four rows of carrots alternating with two, three, and four rows of cowpea, flanked by two rows of carrot on one side and two rows of cowpea on the other side, thus forming lateral borders. The total areas of the plots were $2.40,3.00$, and $3.60 \mathrm{~m}^{2}$ with harvest areas of $1.00,1.50$, and $2.00 \mathrm{~m}^{2}$, respectively.

Single plots of the carrot and cowpea crops were planted in each block to obtain the indicator of agro-economic efficiency of each crop and the intercropping system. The single crop of each vegetable was established by planting six lines per plot with a total area of $1.44 \mathrm{~m}^{2}$ and a harvest area of $0.80 \mathrm{~m}^{2}$, in the spacing of $0.20 \mathrm{~m} \times 0.10 \mathrm{~m}$ for the carrot and of a total area of $3.60 \mathrm{~m}^{2}$ and a harvest area of $2.00 \mathrm{~m}^{2}$, in the spacing $0.50 \mathrm{~m} \times 0.10 \mathrm{~m}$ for the cowpea. The harvest areas were constituted by the central rows of plants, excluding the first and last plants of each row, used as borders. The plant populations recommended for the cultivation of the single crops of cowpea and carrot in the region are 200,000 (EMBRAPA, 2009) and 500,000 (OLIVEIRA et al., 2012) plants per ha, respectively.

A mechanical cleaning of the area was carried out with the aid of a tractor with a coupled plow, followed by a harrowing and lifting of the beds. A solarization, using transparent plastic of $30 \mu \mathrm{m}$ 'Vulcabrilho Bril Fles' was carried out for 57 days to reduce the soil phytopathogen population, which would affect crop productivity.

The green manuring was carried out with rooster tree Calotropis procera (Ait.) R.Br. in all of the experimental plots, collected from the native vegetation at the urban perimeter of Mossoró and Apodi towns, crushed in pieces of $2-3 \mathrm{~cm}$ and placed to dry at room temperature until reaching the hay point, and stored at a moisture content of $8.3 \%$. Samples of green manure were randomly collected for quantification of the nutrient contents, and the chemical composition was $15.3 \mathrm{~g} \mathrm{~kg}^{-1} \mathrm{~N}$; $4.0 \mathrm{~g} \mathrm{~kg}^{-1} \mathrm{P} ; 15.7 \mathrm{~g} \mathrm{~kg}^{-1} \mathrm{~K} ; 9.3 \mathrm{~g} \mathrm{~kg}^{-1} \mathrm{Ca}$ and $7.03 \mathrm{~g} \mathrm{~kg}^{-1} \mathrm{Mg}$, with a carbon/nitrogen ratio of $25: 1$.

A total of $51 \mathrm{t} \mathrm{ha}^{-1}$ of the green manure was added, over two separate sessions, to the intercropped and single-crop plots, with $40 \%$ of the rooster tree being incorporated 20 days before sowing the component crops, and the $60 \%$ remaining incorporated 40 days after the planting of carrot and cowpea.

The sowing of the carrot and cowpea occurred on October 22, 2013, in holes of approximately $3 \mathrm{~cm}$ depth. Two to three seeds were placed per hole for the carrot and two seeds per hole were placed for the cowpea. The thinning of carrot and cowpea was carried out at 20 and 9 days after planting, respectively. One week before harvesting, 20 plants were identified randomly from each experimental plot to obtain the data.

The irrigation of the experiment was performed by micro-sprinkler, in two shifts of daily watering in the morning and afternoon, with a daily water quota of approximately $8 \mathrm{~mm}$ per crop in order to maintain soil moisture between $50 \%$ and $70 \%$ of field capacity (PORTO et al., 2011). For weed control, manual weeding was performed at 15,30 , and 35 days after sowing.

The carrot harvest occurred at 105 days after sowing. Three harvestings of cowpea occurred at 57 , 63 , and 67 days after sowing.

The characteristics evaluated in the carrot crop were commercial productivity (quantified from the fresh mass of the long, medium and short roots of the useful area of the plot, expressed in $\mathrm{tha}^{-1}$, and lack of cracks, bifurcations, nematodes and mechanical damage), total productivity (obtained by adding commercial productivity to productivity of scrap roots, expressed in $\mathrm{t} \mathrm{ha}^{-1}$ ) and classified productivity of roots, obtained according to length and greatest transverse diameter in long (length of 17 to $25 \mathrm{~cm}$ and diameter greater than $5 \mathrm{~cm}$ ), medium (length of 12 to $17 \mathrm{~cm}$ and diameter greater than $2.5 \mathrm{~cm}$ ), short (length of 5 to $12 \mathrm{~cm}$ and diameter greater than $1 \mathrm{~cm}$ ) and scrap (do not fit in the previous measures) roots, according to the methodology used by Bezerra Neto et al. (2014), expressed in $\mathrm{t} \mathrm{ha}^{-1}$.

The following characteristics were evaluated for green cowpea: number of green pods per square meter (determined by quantification of pods harvested from plants in the harvest area), length of pods (determined in a random sample of 20 plants, measured with a ruler and expressed in centimeters), productivity of green pods (quantified from all pods harvested from the plants of the harvest area, expressed in kilograms per hectare), number of green grains per pod (obtained from the sample of 20 plants harvested at random in the harvest area of each plot), weight of 100 green grains (obtained from four random samples of 100 green grains, expressed in grams) and productivity of green grains (determined by the quantity of green grains obtained from the harvest area of each plot, expressed in kilograms per hectare).

In order to determine the optimum agro-economic efficiency of the intercropping systems, the data were analyzed using the modified monetary advantage (MMA), obtained by the following equation:

$\mathrm{MMA}=\mathrm{NI} \times($ LER -1$) / \mathrm{LER}$, where:

MMA $=$ Modified monetary advantage $\left(\mathrm{R} \$\right.$ ha $\left.^{-1}\right)$;

$\mathrm{NI}=$ Net income per hectare $\left(\mathrm{R} \$ \mathrm{ha}^{-1}\right)$, represented by the equation $\mathrm{NI}=\mathrm{GI}-\mathrm{TC}$;

$\mathrm{LER}=$ Land equivalent ratio;

$\mathrm{GI}=$ Gross income;

$\mathrm{TC}=$ Total costs of the production.

The methodology to obtain TC it was found in Silva et al. (2015), where the total costs of the

Rev. Caatinga, Mossoró, v. 31, n. 1, p. 19 - 27, jan. - mar., 2018 
production were calculated at the end of the production process, based on the total expenditures per hectare of the cultivated area, which cover the services provided by the stable capital, that is, the working capital contribution and the alternative costs value.

The LER for the intercropping system was defined by the following expression:

$\mathrm{LER}=\left(\mathrm{Y}_{\mathrm{ccv}} / \mathrm{Y}_{\mathrm{sc}}\right)+\left(\mathrm{Y}_{\mathrm{cvc}} / \mathrm{Y}_{\mathrm{scv}}\right)$, where the following is true:

$\mathrm{Y}_{\mathrm{ccv}}=$ Commercial productivity of carrot roots in intercropping with cowpea;

$\mathrm{Y}_{\mathrm{cs}}=$ Commercial productivity of carrot roots in the single crop;

$\mathrm{Y}_{\mathrm{cvc}}=$ Productivity of green grains of cowpea in intercropping with carrot;

$\mathrm{Y}_{\mathrm{cvs}}=$ Productivity of green grains of cowpea in the single crop.

The LERs of each plot were obtained through the mean value of the replications of the single crops over blocks in the denominator of the partial LER of each crop (LERc and LERcv), according to the methodology used by Bezerra Neto et al. (2012).

We performed univariate analyzes of variance on the variables determined through the statistical package SISVAR (FERREIRA, 2011) for the randomized complete block design, with the treatments arranged in a factorial scheme. Tukey's test at the 5\% probability level was used to compare the means of the spatial arrangements of the component cultures. Adjustment procedure of the response curves was performed for each variable as a function of population density.

\section{RESULTS AND DISCUSSION}

\section{Carrot crop}

There was no significant interaction between spatial arrangement and population density of cowpea in the commercial and total productivity of carrot roots. However, significant differences between spatial arrangements were observed for these two variables (Table 1 and Figure 1). The 2:2 and $4: 4$ arrangements, with statistically similar mean values, differed from $3: 3$ in the commercial productivity. On the other hand, the $2: 2$ arrangement differed from the $3: 3$ and $4: 4$ arrangements in total productivity, although the latter two did not differ statistically (Table 1).

Table 1. Commercial (CP) and total (TP) productivity of carrot roots in intercropping with cowpea as a function of spatial arrangements.

\begin{tabular}{|c|c|c|}
\hline \multirow[b]{2}{*}{ Spatial arrangements } & \multicolumn{2}{|c|}{ Variables analyzed } \\
\hline & $\begin{array}{c}\mathrm{CP} \\
\left(\mathrm{t} \mathrm{ha}^{-1}\right)\end{array}$ & $\begin{array}{c}\text { TP } \\
\left(\mathrm{t} \mathrm{ha}^{-1}\right)\end{array}$ \\
\hline $2: 2$ & $24.75 \mathrm{a}$ & $26.80 \mathrm{a}$ \\
\hline $3: 3$ & $21.07 \mathrm{~b}$ & $22.68 \mathrm{~b}$ \\
\hline $4: 4$ & $21.81 \mathrm{a}$ & $23.65 \mathrm{~b}$ \\
\hline
\end{tabular}

*Means followed by different lowercase letters in the column differ statistically by Tukey test at $5 \%$ probability.

For the commercial and total carrot root productivity, the highest values occurred in the 2:2 spatial arrangement, where the smallest intra- and interspecific competitions were recorded in comparison to 3:3 and 4:4 spatial arrangements. The best use of environmental resources took place in the $2: 2$ arrangement.

It was not possible to adjust a response equation for commercial and total carrot root productivity as a function of population density of cowpea (Figures 1A, 1B). LIMA et al. (2013) state that as spacing decreases and population density increases, within certain limits, there is an increase in total production per area, resulting in greater profitability for the producer.

There was no significant interaction between the spatial arrangement and population density of cowpea in the productivity of long, medium, short, and scrap roots of the carrot intercropped with cowpea (Table 2 and Figure 2). However, significant differences between the mean values of these variables in the spatial arrangements were only recorded in the long root productivity, with the $2: 2$ arrangement standing out from the $3: 3$ and $4: 4$ arrangements (Table 2).

It was not possible to adjust a response equation for the long, medium, and short root productivity as a function of population density of cowpea (Figures 2A, 2B, and 2C). This behavior was also observed in these characteristics by Oliveira et al. (2011), who evaluated the agronomic performance of the carrot fertilized with hairy woodrose before sowing. 
A

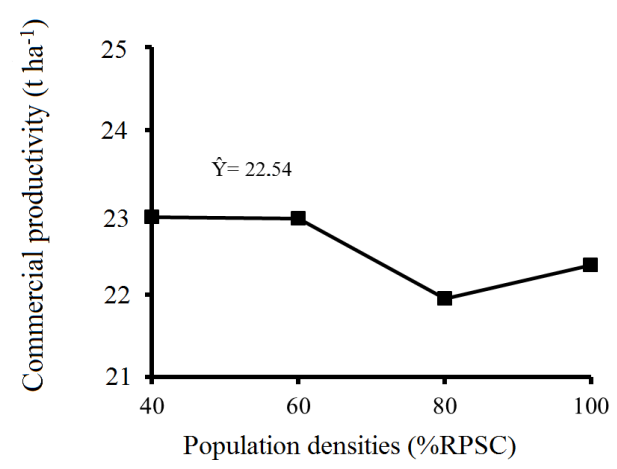

B

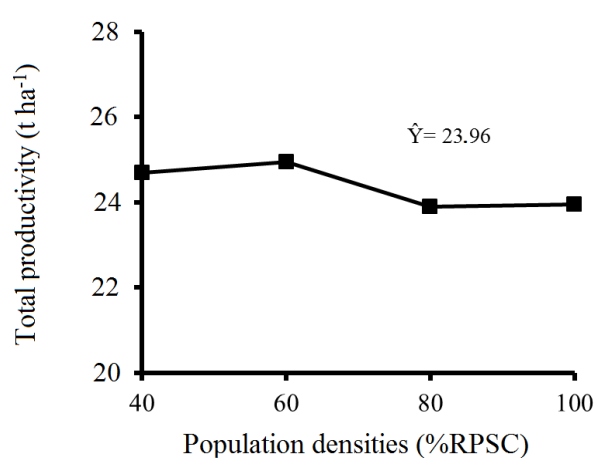

Figure 1. Commercial (A) and total (B) productivity of carrot roots in intercropping with cowpea as a function of population density of cowpea.

Table 2. Productivity of long (LR), medium (MR), short (SR) and scrap (ScR) roots of the carrot intercropped with cowpea as a function of spatial arrangements.

\begin{tabular}{|c|c|c|c|c|}
\hline \multirow[b]{2}{*}{ Spatial arrangements } & \multicolumn{4}{|c|}{ Variables analyzed } \\
\hline & $\begin{array}{c}\text { LR } \\
\left(\mathrm{t} \mathrm{ha}^{-1}\right)\end{array}$ & $\begin{array}{c}\text { MR } \\
\left(\mathrm{t} \mathrm{ha}^{-1}\right)\end{array}$ & $\begin{array}{c}\mathrm{SR} \\
\left(\mathrm{t} \mathrm{h \textrm {ha } ^ { - 1 }}\right)\end{array}$ & $\begin{array}{c}\mathrm{ScR} \\
\left.(\mathrm{t} \mathrm{ha})^{-1}\right)\end{array}$ \\
\hline $2: 2$ & $12.61 \mathrm{a}^{*}$ & $9.54 \mathrm{a}$ & $2.59 \mathrm{a}$ & $2.04 \mathrm{a}$ \\
\hline $3: 3$ & $8.21 \mathrm{~b}$ & $9.74 \mathrm{a}$ & $3.11 \mathrm{a}$ & $1.60 \mathrm{a}$ \\
\hline $4: 4$ & $8.73 \mathrm{~b}$ & $9.94 \mathrm{a}$ & $3.13 \mathrm{a}$ & $1.84 \mathrm{a}$ \\
\hline
\end{tabular}

*Means followed by different lowercase letters in the column differ statistically by Tukey test at $5 \%$ probability.

It was not possible to adjust a response equation for the long, medium, and short root productivity as a function of population density of cowpea (Figures 2A, 2B, and 2C). This behavior was

A

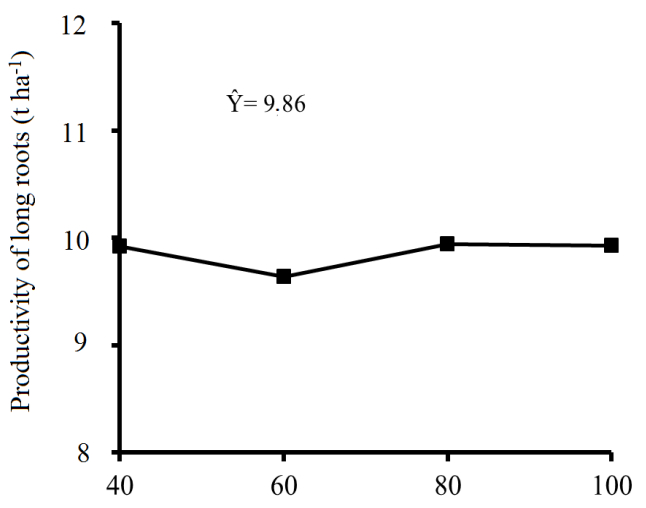

C

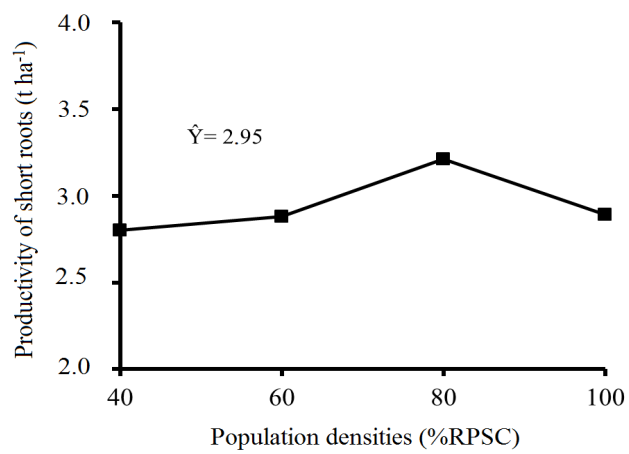

also observed in these characteristics by Oliveira et al. (2011), who evaluated the agronomic performance of the carrot fertilized with hairy woodrose before sowing.

B

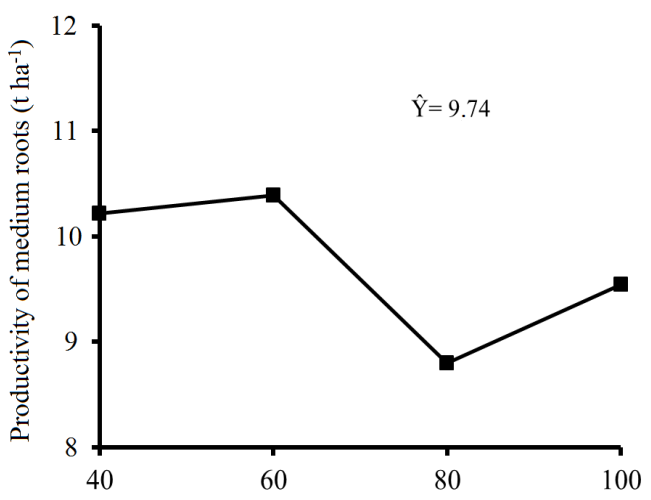

D

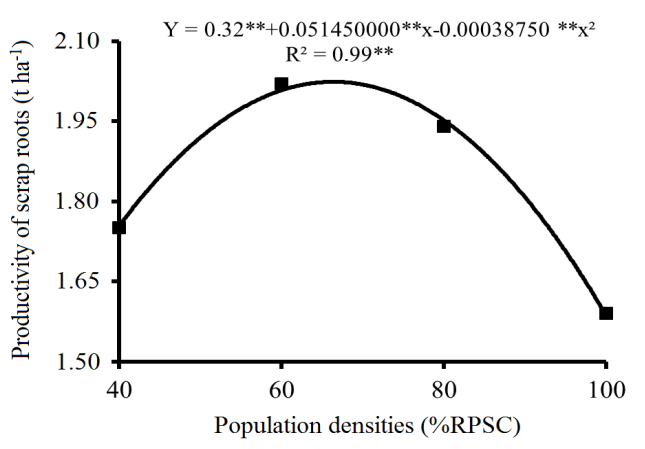

Figure 2. Productivity of long (A), medium (B), short (C), and scrap (D) roots of carrot in intercropping with cowpea as a function of population density of cowpea.

Rev. Caatinga, Mossoró, v. 31, n. 1, p. 19 - 27, jan. - mar., 2018 
For the scrap root productivity, an increase was initially observed in the population density of the cowpea up to a maximum value of $2.03 \mathrm{t} \mathrm{ha}^{-1}$, where the density of cowpea was $66 \%$ of the RPSC, and the productivity then decreased until the highest density (Figure 2D).

An increase in population density can influence the quality of tuberous roots, increasing the number of fine roots and reducing the average size of these roots due to the greater competition for water and nutrients imposed on the plants. The management of plant density has an important role in increasing the efficiency of the canopy in intercepting the incident radiation in relation to the time and unit of area. Oroka and Omoregie (2007) emphasize that an increase in population density may increase the interception of solar radiation and the efficiency of its use.

\section{Cowpea crop}

There was no significant interaction between spatial arrangement and population density of cowpea for number of green pods per square meter, length of green pods, productivity of green pods, number of green grains per pod, weight of 100 green grains, and productivity of green grains (Table 3 and Figures 3 and 4).

Similarly, no significant differences were observed between spatial arrangements $(2: 2,3: 3$, and $4: 4)$ in these analyzed variables (Table 3 ). This means that the use of environmental resources for spatial arrangements and the development and production of these variables was similar, to the point of not promoting differentiation between them.

According to Vandermeer (1989), this happens when one species provides a benefit to another, altering the environment of another species in a positive way, or when the two cultures use different components of the environment, that is, when the crops exploit the environmental niches distinctly.

Table 3. Number of green pods per area (NGP $\mathrm{m}^{-2}$ ), length of green pods (LGP), productivity of green pods (PGP), number of green grains per pod (NGGP), weight of 100 green grains (P100G), and productivity of green grains (PGV) of cowpea intercropped with carrot as a function of spatial arrangements.

\begin{tabular}{ccccccc}
\hline \multirow{2}{*}{$\begin{array}{c}\text { Spatial } \\
\text { arrangements }\end{array}$} & \multicolumn{7}{c}{ Variables analyzed } \\
\cline { 2 - 7 } & $\mathbf{N G P ( \mathbf { m } ^ { - 2 } )}$ & $\begin{array}{c}\text { LGP } \\
(\mathbf{c m})\end{array}$ & $\begin{array}{c}\text { PGP } \\
\left(\mathbf{k g ~ h a}^{-1}\right)\end{array}$ & NGGP & $\begin{array}{c}\text { W100GG } \\
(\mathbf{g})\end{array}$ & $\begin{array}{c}\text { PGG } \\
\left(\mathbf{k g ~ h a}^{-1}\right)\end{array}$ \\
\cline { 2 - 7 } & $30.18 \mathrm{a}$ & $11.07 \mathrm{a}$ & $1,116.15 \mathrm{a}$ & $5.55 \mathrm{a}$ & $17.39 \mathrm{a}^{*}$ & $622.08 \mathrm{a}$ \\
$2: 2$ & $27.08 \mathrm{a}$ & $11.50 \mathrm{a}$ & $989.61 \mathrm{a}$ & $5.57 \mathrm{a}$ & $18.69 \mathrm{a}$ & $517.36 \mathrm{a}$ \\
$3: 3$ & $28.53 \mathrm{a}$ & $12.75 \mathrm{a}$ & $1,072.98 \mathrm{a}$ & $5.77 \mathrm{a}$ & $29.07 \mathrm{a}$ & $581.01 \mathrm{a}$ \\
$4: 4$ & &
\end{tabular}

*Means followed by different lowercase letters in the column differ statistically by Tukey test at $5 \%$ probability.

It was not possible to adjust a response equation for length of green pods and weight of 100 green grains of cowpea as a function of population density of cowpea (Figures 3A and 3B).

However, when cowpea variables were analyzed as a function of population density, response equations for number of green pods per area, productivity of green pods, number of green grains per pod and productivity of green grains were found (Figures 4A, 4B, 4C, and 4D).
A

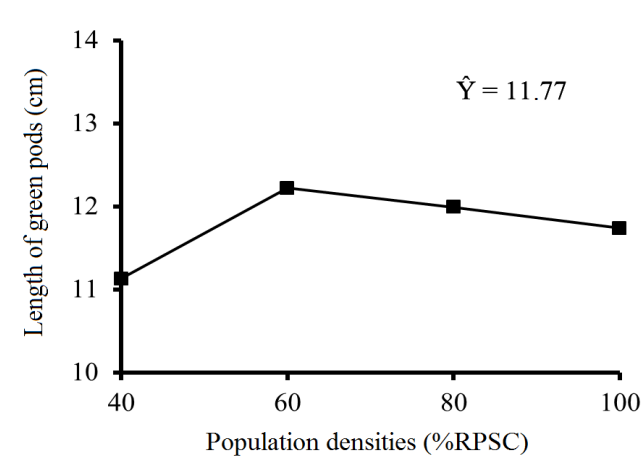

B

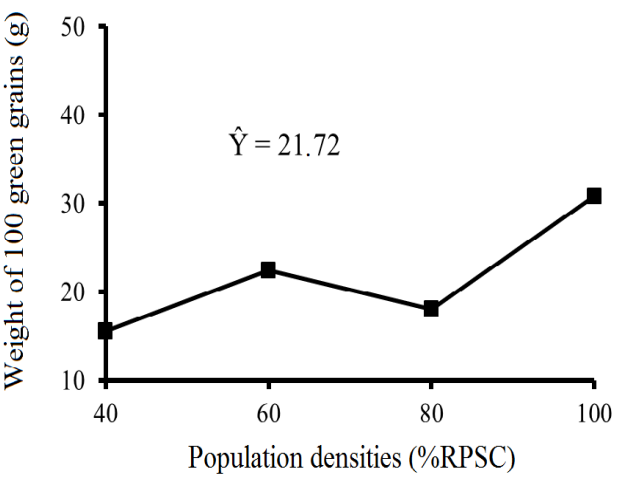

Figure 3. Length of green pods (A) and weight of 100 green grains (B) of cowpea in intercropping with carrot as a function of population density of cowpea. 
A

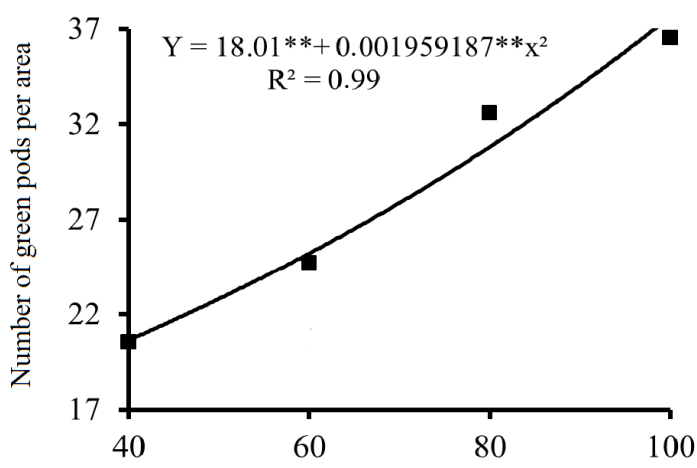

C

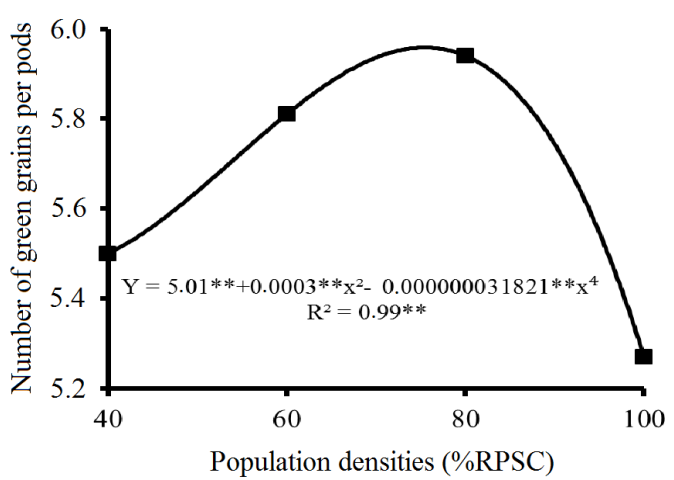

B

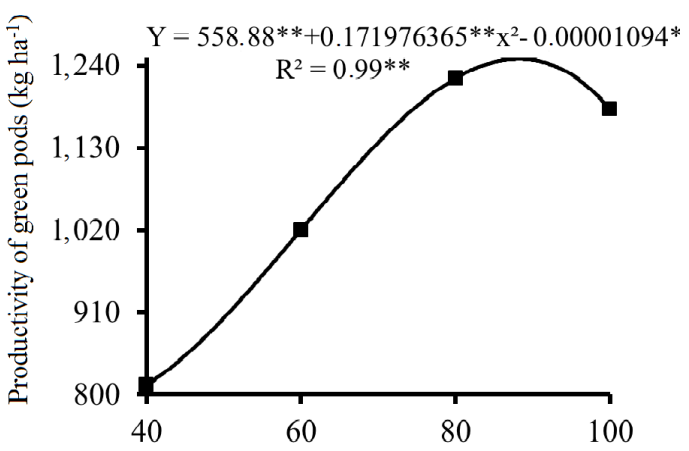

D

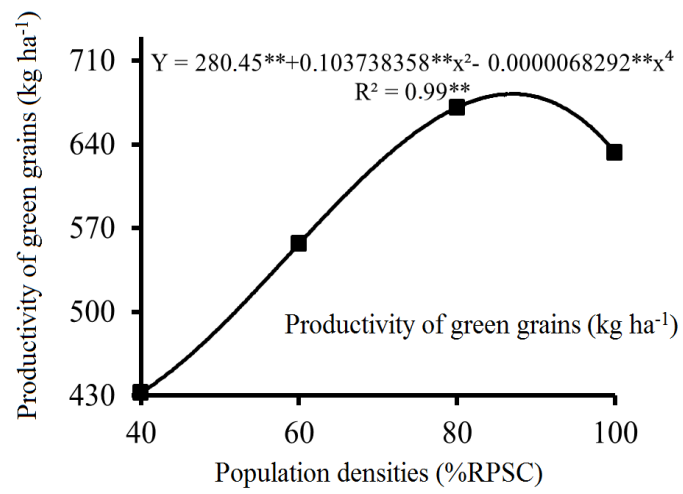

Figure 4. Number of green pods per area (A), productivity of green pods (B), number of green grains per pods (C), and productivity of green grains (D) of cowpea in intercropping with carrot as a function of population density of cowpea.

For the number of green pods per area it was verified that as the population of the cowpea increased, there was an increase of this characteristic, reaching the maximum value of 37.60 at a population density of $100 \%$ RPSC (Figure 4A). This is because the greater number of plants per area provided greater intraspecific competition between plants.

For the productivity of green pods by area, number of green grains per pod and productivity of green grains, an increase was observed with the population density of cowpea up to the values of $1,234.73 \mathrm{~kg} \mathrm{ha}^{-1}, 5.95$ and $674.40 \mathrm{~kg} \mathrm{ha}^{-1}$, at the cowpea densities of $88.6 \% ; 73.5 \%$, and $87.2 \%$ of the RPSC, respectively, then decreasing until the highest density studied (Figures 4B, 4C and 4D).

\section{Agro-economic indicator}

\section{Modified monetary advantage}

There was no significant interaction between spatial arrangement and population density of cowpea for modified monetary advantage, and there were also no significant differences between spatial arrangements (Table 4). Favacho (2015) in a study of the intercropping of carrot $\times$ cowpea as a function of amount of rooster tree biomass and spatial arrangements also showed no significant interaction between the treatments factors studied in the modified monetary advantage. Although there were no significant differences among the arrangements studied, the 2:2 arrangement in absolute terms was superior to the others, presenting an average value of $\mathrm{R} \$$ 6,728.10. This behavior can probably be attributed to the low competition in this arrangement.

Table 4. Modified monetary advantage (MMA) of carrot intercropped with cowpea as a function of spatial arrangements.

\begin{tabular}{cr}
\hline Spatial arrangements & $\begin{array}{c}\text { MMA } \\
\left(\mathbf{R S ~ h a}^{-1}\right)\end{array}$ \\
\hline $2: 2$ & $6,728.16 \mathrm{a}$ \\
$3: 3$ & $4,446.00 \mathrm{a}$ \\
$4: 4$ & $4,674.00 \mathrm{a}$ \\
\hline
\end{tabular}

*Means followed by different lowercase letters in the column differ statistically by Tukey test at $5 \%$ probability. 
It was possible to adjust the response equation for modified monetary advantage as a function of population density of cowpea (Figure 5). An increase was observed, reaching a maximum value of $\mathrm{R} \$$
$5,996.84$ per hectare at a cowpea density of $42 \%$ of the RPSC, with a decrease in its value with an increase in cowpea population density.

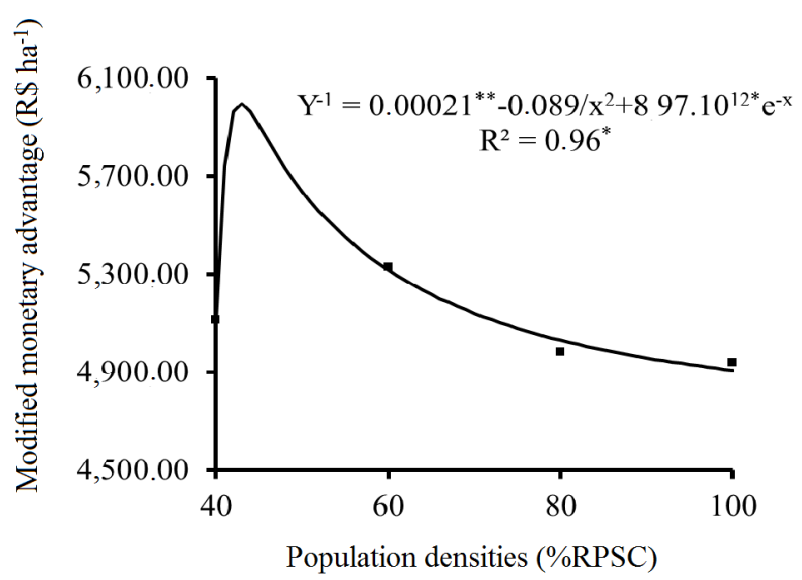

Figure 5. Modified monetary advantage of the carrot intercropping with cowpea as a function of population density of cowpea.

The results found for this agro-economic index show the agronomic-biological superiority of the intercropping system in relation to single crops through the favorable use of environmental resources. Oliveira et al. (2015), in a study on the agronomic viability of arugula-carrot-lettuce polycultures in different amounts of rooster tree and population densities of the component crops, also observed intercropping to be advantageous in comparison to the single crops with regards to the modified monetary advantage. As can be seen, the agronomic advantage also guaranteed an economic advantage in the intercropping system.

\section{CONCLUSION}

No influence of the spatial arrangements between the component cultures on the agroeconomic performance of carrot $\times$ cowpea intercropping was observed.

The highest agro-economic performance of the intercropping of carrot $\times$ cowpea was obtained when the population of cowpea was $42 \%$ of the RPSC.

\section{ACKNOWLEDGEMENTS}

Special thanks are due to the Coordenação de Aperfeiçoamento de Pessoal de Nível Superior for financial support of this research, and to the research group of the Plant Science Department of the Universidade Federal Rural do Semi-Árido (UFERSA), which develops technologies for growing vegetables on family farms.

\section{REFERENCES}

ALTIERI, M.; SILVA E. N.; NICHOLLS, C. O papel da biodiversidade no manejo de pragas. Ribeirão Preto, SP: Editora Holos, 2003. 226 p.

BEZERRA NETO, F. et al. Associação de densidades populacionais de cenoura e alface no desempenho agronômico da cenoura em cultivo consorciado em faixa. Horticultura Brasileira, Brasília, v. 23, n. 2, p. 233-237, 2005.

BEZERRA NETO, F. et al. Assessment of agroeconomic indices in polycultures of lettuce, rocket and carrot through uni- and multivariate approaches in semi-arid Brazil. Ecological Indicators, Amsterdam, v. 14, n. 1, p. 11-17, 2012.

BEZERRA NETO, F. et al. Otimização agroeconômica da cenoura fertilizada com diferentes doses de jitirana. Revista Ciência Agronômica, Fortaleza, v. 45, n. 2, p. 305-311, 2014.

CECÍlIO FILHO, A. B.; REZENDE, B. L. A.; CANATO, G. H. D. Produtividade de alface rabanete em cultivo consorciado estabelecido em diferentes épocas e espaçamentos entre linhas. Horticultura Brasileira, Brasília, v. 25, n. 3, p. 15 $19,2007$.

CECÍLIO FILHO, A. B. et al. Agronomic efficiency of intercropping tomato and lettuce. Anais da Academia Brasileira de Ciências, Rio de Janeiro, v. 83, n. 3, p. 1109-1119, 2011

EMPRESA BRASILEIRA DE PESQUISA AGROPECUÁRIA - EMBRAPA. BRS Itaim: 
cultivar de feijão-caupi com grãos tipo fradinho. Teresina: Embrapa Meio-Norte, 2009. (folder).

FAVACHO, F. S. Eficiência agroeconômica do consorcio cenoura $x$ caupi-hortaliça em função de quantidades de biomassa de flor-de-seda e arranjos espaciais. 2015. $73 \mathrm{f}$. Tese (Doutorado em Fitotecnia: Agricultura Tropical) - Universidade Federal Rural do Semi-Árido, Mossoró, 2015.

FERREIRA, D. F. Sisvar: A computer statistical analysis system. Ciência e Agrotecnologia, Lavras, v. 35 , n. 6 , p. 1039-1042, 2011.

JAUER, A. et al. Comportamento de cultivar pérola de feijoeiro comum (Phaseolus vulgaris L.) em quatro densidades de semeadura na safrinha em Santa Maria - RS. Revista da FZVA, Uruguaiana, v. 13, n. 1, p. 12-23, 2006.

LIMA, J. S. S. et al. Produtividade da cenoura, coentro e rúcula em função de densidades populacionais. Revista Verde de Agroecologia e Desenvolvimento Sustentável, Mossoró, v. 8, n. 1, p. 110-116, 2013.

LOPES, W. A. R. et al. Produtividade de cultivares de cenoura sob diferentes densidades de plantio. Revista Ceres, Viçosa, v. 55, n. 5, p. 482-487, 2008.

OLIVEIRA, L. A. A. et al. Viabilidade agronômica de policultivos de rúcula/cenoura/alface sob quantidades de flor-de-seda e densidades populacionais. Revista Caatinga, Mossoró, v. 28, n. 4, p. 116-126, 2015.

OLIVEIRA, M. K. T. et al. Desempenho agroeconômico da cenoura adubada com jitirana (Merremia aegyptia). Horticultura Brasileira, Brasília, v. 30, n. 3, p. 433-439, 2012.

OLIVEIRA, M. K. T. et al. Desempenho agronômico da cenoura adubada com jitirana antes de sua semeadura. Revista Ciência Agronômica, Fortaleza, v. 42, n. 2, p. 364-372, 2011.

OROKA, F. O.; OMEREGIE, A. U. Competition in a rice-cowpea intercrop as affected by nitrogen fertilizer and plant population. Scientia Agricola, Piracicaba, v. 64, n. 6, p. 621-629, 2007.

PORTO, V. C. N. et al. Combination of lettuce and rocket cultivars in two cultures intercropped with carrots. Horticultura Brasileira, Brasília, v. 29, n. 3, p. 404-411, 2011.

SILVA, A. F. A. et al. Rentabilidade do rabanete adubado com flor-de-seda em duas épocas de cultivo no semiárido de Pernambuco. Revista de Ciências
Agrárias/Amazonian Journal of Agricultural and Environmental Sciences, Manaus, v. 58, n. 2, p. 198-207, 2015.

VANDERMEER, J. H. The ecology of intercropping. Cambridge: Cambridge University Press, 1989. 237 p.

ZANINE, A. M.; SANTOS, E. M. Competição entre espécies de plantas: Uma revisão. Revista da Faculdade de Zootecnia, Veterinária e Agronomia, Uruguaiana, v. 11, n. 1, p. 10-30, 2004. 